\title{
Recharge source identification using isotope analysis and groundwater flow modeling for Puri city in India
}

\author{
P. C. Nayak $^{1}$ (I) S. V. Vijaya $\operatorname{Kumar}^{1}$ - P. R. S. Rao ${ }^{1} \cdot$ T. Vijay ${ }^{1}$
}

Received: 18 January 2016/Accepted: 28 October 2016/Published online: 14 November 2016

(c) The Author(s) 2016. This article is published with open access at Springerlink.com

\begin{abstract}
The holy city of Lord Jagannath is situated on the sea shore of the Bay of Bengal in Odisha state in India. Puri is a city of high religious importance and heritage value, details of the rituals, fairs, and festivals, and related aspects are covered extensively. It is found that water levels in two wells (Ganga and Yamuna) are declining and the causes are studied by undertaking modeling study of rainfall-recharge processes, surface water-groundwater interactions, and increasing demands due to urbanization at basin scale. Hydrochemical analysis of groundwater samples indicates that $\mathrm{pH}$ value is varying from 7 to 8.4 and electrical conductivity (EC) is found in between 238 and $2710 \mu \mathrm{mhos} / \mathrm{cm}$. The EC values indicate that the shallow groundwater in Puri is not saline. Stable isotopic signatures of O-18, Deuterium indicate two different sources are active in the city area. In most of the handpumps, water recharged by the surface water sources. From the current investigation, it is evident that in a few handpumps and most of the dug-wells, isotopic signatures of water samples resembles with local precipitation. The groundwater recharge is taking place from the north-southern direction. Visual MODFLOW has been used for studying groundwater aspects and different scenarios have been developed. It is suggested to maintain water level in Samang Lake to restore depletion in groundwater level in two wells.
\end{abstract}

Keywords Groundwater - Isotope analysis · Recharge · Flow modeling $\cdot$ MODFLOW

\footnotetext{
P. C. Nayak

nayakpc@yahoo.co.in
}

1 Deltaic Regional Centre, National Institute of Hydrology, Siddartha Nagar, Kakinada, AP 533 003, India

\section{Introduction}

Puri, the holy city of Odisha has a remarkable value in the field of art, architecture, literature, religion, and tradition. Puri is the seat of Lord Jagannath, the Lord of Universe. This place is an important religious centre for Hindus. The sanctity of the place is well known to all the pilgrims of the world. During the British Rule, Puri municipality was formed in 1881 as per the recommendation of D. Smith. During the period 1822-1826, Puri city was connected with Calcutta by road. Puri is an important ancient town of Odisha. It always attracts number of pilgrims, devotees, visitors, and scholars. Puri city occupies a high position in the sky of religious work. Its contribution in the field of religion and culture is far reaching.

This holy city's sacredness is inherent in the sacred 'Mahaprasad (sacred food items)' of Lord Sri Jagannath. Mahaprasad includes cooked rice, dal, vegetable curry, sweet-dishes, cakes, etc. Dry confectionaries are prepared of sugar, jaggary, wheat flour, ghee, milk, and cheese, etc. and offered to God. It is on record that as many as 56 items of food were being offered to the deities at Madhyana Dhupa (lunch) since 1910. The 'Anand Bazar' of Sri Mandir (temple) can feed more than 1 lakh people in a day and 60 quintals of rice are cooked every day. In this holy city, the pilgrims and tourists get the sumptuous taste of several varieties of nutritious Orissan food in typical Oriya recipes. For making Mahaprasad and to meet the activities of Anand Bazar and temple rituals, water from two open wells called Ganga and Jamuna are utilized actively. Recently, it has been reported that two wells are unable to provide sufficient water for temple activities. Therefore, it is very important to determine the causes owing to decline in groundwater water level by undertaking modeling study of rainfall-recharge processes, recharge area identification 
using stable isotope analysis, surface water-groundwater interactions, and increasing demands due to urbanization at basin scale.

Recharge of groundwater is one critical aspect in resource management, and isotopes can help determine both the area and the rate of recharge. The area can be identified by measuring ${ }^{2} \mathrm{H}$ and ${ }^{18} \mathrm{O}$ concentrations and correlating them to the altitude at which precipitation could have infiltrated the ground. The rate can be measured by tracing levels of radioactive tritium in soil at various depths. In many instances, the tritium "peak" can be found at considerable depths, which indicates the distance travelled by the moisture since being deposited as tritium fallout in 1963. Isotopes can provide preliminary indications of the flow paths and origins of the water. This information is important to access the groundwater during drilling. Radioactive and non-radioactive or "stable" isotope information is, thereafter, integrated with other available data to produce a comprehensive hydrological concept of the groundwater system.

Several researchers reported various applications of environmental isotopes in hydrologic studies, such as identification of source of recharge and estimation of groundwater quantity, quality, dating and their interconnections; seepage from canals, reservoirs, tunnels, etc. estimation of fraction of snow melt and ice melt in glacier discharges; dynamics, and sedimentation in lakes. Yehdeghoa et al. (1997) determined the water balance of small dredging lakes located in the climatic zones and their impact on the adjacent groundwater field using heavy stable isotopes of water, deuterium, and O-18. Rao et al. (2001) employed isotope techniques to study the dynamics and sedimentation patterns of lake Naini, India. A tritium and water balance coupled model was developed and allows for the estimation of lake and groundwater residence time. Gibson et al. (2002) made a isotope-based approach and water balance assessment to estimate the throughflow, residence time, and catchment runoff to 70 headwater lakes on the Borreal plain and uplands of northern and north-central Alberta, Canada. Vandenschrick et al. (2002) focus on the $\delta^{18} \mathrm{O}-\delta \mathrm{D}$ relationships of local precipitation to explain the isotopic variability of large karstic aquifers. The isotopic composition of groundwater sampled along altitudinal gradient from the recharge zone to coastal plain is defined. Gibson (2002) found that evaporation rates predominantly control the rates of isotopic enrichment in small shallow lakes in a continental, low Arctic setting due to extreme seasonality and extreme departures from isotopic steady state during ice free period. Gurrieri and Furniss (2004) found that the degree of groundwater inflow differs widely between lakes ranging from negligible to direct communication with the local ground water system. For lakes with groundwater inflow, a major portion of the solute load is contributed by groundwater compared with other inputs.

Mayr et al. (2007) made a stable isotope data base $\left(\delta^{2} \mathrm{H}\right.$ and $\left.\delta^{18} \mathrm{O}\right)$ for estimating evaporation to inflow ratios $(E /$ $I)$ and water balances of lakes in semi-arid southern Patagonia. Further precipitation, groundwater and atmospheric water vapor were sampled for isotope analyses. Brock and Edwards (2007) developed a new coupled isotope tracer method for characterizing the isotopic composition of input water to lakes, and apply it in the context of ongoing hydrological process studies in the Peace-Athabasca Delta in the boreal region of Western Canada. Blasch and Bryson (2007) estimated stable isotopes of hydrogen and oxygen from precipitation and ground water were used to infer locations where ground water is recharging in regional-sized basins. Longinelli et al. (2008) made measurements of the isotopic composition of surface water samples of the garda lake carried out between 1998 and 2006 and showed constant $\delta^{18} \mathrm{O}, \delta \mathrm{D}, \mathrm{d}$-excess values through time. The isotopic composition of the groundwater is close to the mean isotopic composition of precipitations in the area and catchment basin. Demlie et al. (2007) study intends to provide basic data for the scientific community and water resource developers which involve estimating the components of hydrologic cycle. The hydraulic relation of the lakes and surface water and groundwater interaction also got addressed. Shivanna et al. (2008) employed environmental isotope techniques to identify the recharge areas of springs in mountainous region of Gaucher area, Chamoli district, Uttarakhand, India. Brock et al. (2009) applied a coupled isotope tracer model to quantify end of thaw season lake water balance in the Slave River Delta, Canada during 2003-2005 which effectively differentiates the relative importance of hydrological processes across the complex freshwater landscape. Yeh et al. (2009) reported the stable isotopes of oxygen and hydrogen were used as tracers to determine the seasonal contributions of precipitation and river water to the groundwater in ChihPen and Jin-Lun Creek basins. Turner et al. (2010)employed isotopic evolution in $\delta^{18} \mathrm{O}-\delta^{2} \mathrm{H}$ space, input water composition $(\delta 1)$, evaporation to inflow ratios, and field observation studies to identify snowmelt dominated, rainfall dominated, groundwater influenced, evaporation dominated, and drained type lakes influencing the lake water balance. V́azquez-Sũńe et al. (2010) reported use of isotope analysis to identify urban groundwater recharge for Barcelona city aquifer. Shaw et al. (2013) monitored lake surface elevations and water table fluctuations to study the local aquifer characteristics. Some of the studies are reported on the origin of groundwater resources, evaporation, and the state of the waters and the depth of the water table (Wassenaar et al. 2011; Babka et al. 2011; Vodila et al. 2011). 
In a study to trace groundwater salinization processes in coastal aquifers in Italy, Mongelli et al. (2013) analyzed the use of stable isotopes and observed from the $\delta^{18} \mathrm{O}$ and $\delta \mathrm{D}$ plot that most of the waters fall between the regional meteoric water line and the global meteoric water line, to indicate that are meteoric in origin. Sharma and Tyagi (2014) reported that there are several conventional methods exist to study the different hydrological processes for a variety of water resources. Recently, a few studies are reported on ground water and tap water across South Africa (West et al. 2014); composition of springs and rain water in various sampling sites of Western Crete (Dimitriou and Tsintza 2015); ground water recharge, groundwater surface water interaction, ground water salinization, and contamination studies (Sharma et al. 2015; Ali et al. 2015; Isokangas et al. 2015).

The hydrological phenomena in a watershed are not independent events, but rather interactive feedbacks between hydrologic processes. Comprehensive and quantitative understanding of hydrologic feedback processes is important for the effective water budget and the provision against potential risks to water resources (Winter et al. 1998; Guo 2002; Brooks et al. 2003; Ward and Trimble 2004; Brutsaert 2005; Gupta 2010). Various techniques and models have been developed to estimate the hydrologic processes. To avoid the overdraft and declining groundwater level, it is important to understand the behavior of an aquifer system subjected to artificial stresses. Simulation modeling is an excellent tool to achieve this goal. Groundwater simulation models are useful in simulating groundwater flow scenarios under different management options and thereby taking corrective measures for sustainable use of water resources by conjunctive use of surface water and groundwater.

During the last 20 years, various studies have been taken up for groundwater flow simulation in different basins using MODFLOW and other models (e.g., Reichard 1995; Onta and Das Gupta 1995; Ting et al. 1998; Reeve et al. 2001; Lin and Medina 2003; Rodriguez et al. 2006; Zume and Tarhule 2008; Al-Salamah et al. 2011; Gaur et al. 2011; $\mathrm{Xu}$ et al. 2012). Groundwater flow models have become almost a routine tool of the practicing hydrologist. Yet, surprisingly, a little attention has been given to true verification analysis of studies using these models (Alley and Emery 1986). They concluded with general perspectives on groundwater modeling gained from this post-audit analysis. A spatially distributed water balance model is developed by Batelaan and Smedt (2007) to simulate longterm average recharge depending on land cover, soil texture, topography, and hydrometeorological parameters, which provides a better insight into the sustenance and management of groundwater resources. A groundwater flow model constructed for the Nabogo Basin using
MODFLOW (Lutz et al. 2007) and different scenarios are developed with increased population and decreased rainfall for current and possible rates of recharge and groundwater extraction. Gaur et al. (2011) reported that the groundwater flow model for on the sub-basin of the Banganga River, India, has been developed using MODFLOW. The groundwater of this sub-basin meets the domestic and agricultural demands of Jaipur city in India and the nearby areas. Baldwin et al. (2012) discussed participatory approaches of interpretation and communication of scientific knowledge about groundwater hydrology can assist communities' understanding and acceptance of the need for better management. Xu et al. (2012) presented MODFLOW with SWAP package to simulate a regional groundwater flow problem in Hetao Irrigation District, upper Yellow River basin of north China, and found that the simulated water table elevations matched well with the observed ones except at the early period during which they were slightly higher than the observed ones. Mohanty et al. (2013) reported a comparison between MODFLOW and the artificial neural network (ANN) model in simulating groundwater levels in an alluvial aquifer system for Mahanadi deltaic system. Recent studies are reported using MODFLOW to simulate groundwater flow and interaction with surface water components (Park et al. 2013, Su et al. 2014); Simon et al. (2015) assess MODFLOW and MT3D capabilities for simulating the spread of contaminants.

In the Puri district, groundwater utilization for irrigation is quite limited and stage of groundwater development as per Groundwater Estimation Committee (GEC 1997) is $7.23 \%$. Thus, there is a large scope for groundwater development for augmenting irrigation potentials and agricultural production. Groundwater is also a dependable source for drinking water. In this context, an attempt has been made to compile and analyze all available hydrogeological and hydrochemical data. In the current investigation, an attempt has been made to identify recharge source and estimate probable contribution from different sources to groundwater recharge using stable isotope analysis for Puri city in Odisha. Visual MODFLOW has been used for studying groundwater aspects to sustain groundwater resources.

\section{Study area details}

\section{Location}

The study area of Puri city (Fig. 1) lies between $19^{\circ} 44^{\prime}-$ $19^{\circ} 58^{\prime}$ north latitudes and $85^{\circ} 42^{\prime}-85^{\circ} 54^{\prime}$ East longitudes falling in Survey of India Toposheet No. $74 E, I, 73 \mathrm{H}, \mathrm{L}$ situated near the sea shore of Bay of Bengal. It is situated $65 \mathrm{~km}$ away from Bhubaneswar, the administrative capital 
Fig. 1 Plot showing study area map of Puri city in Odisha

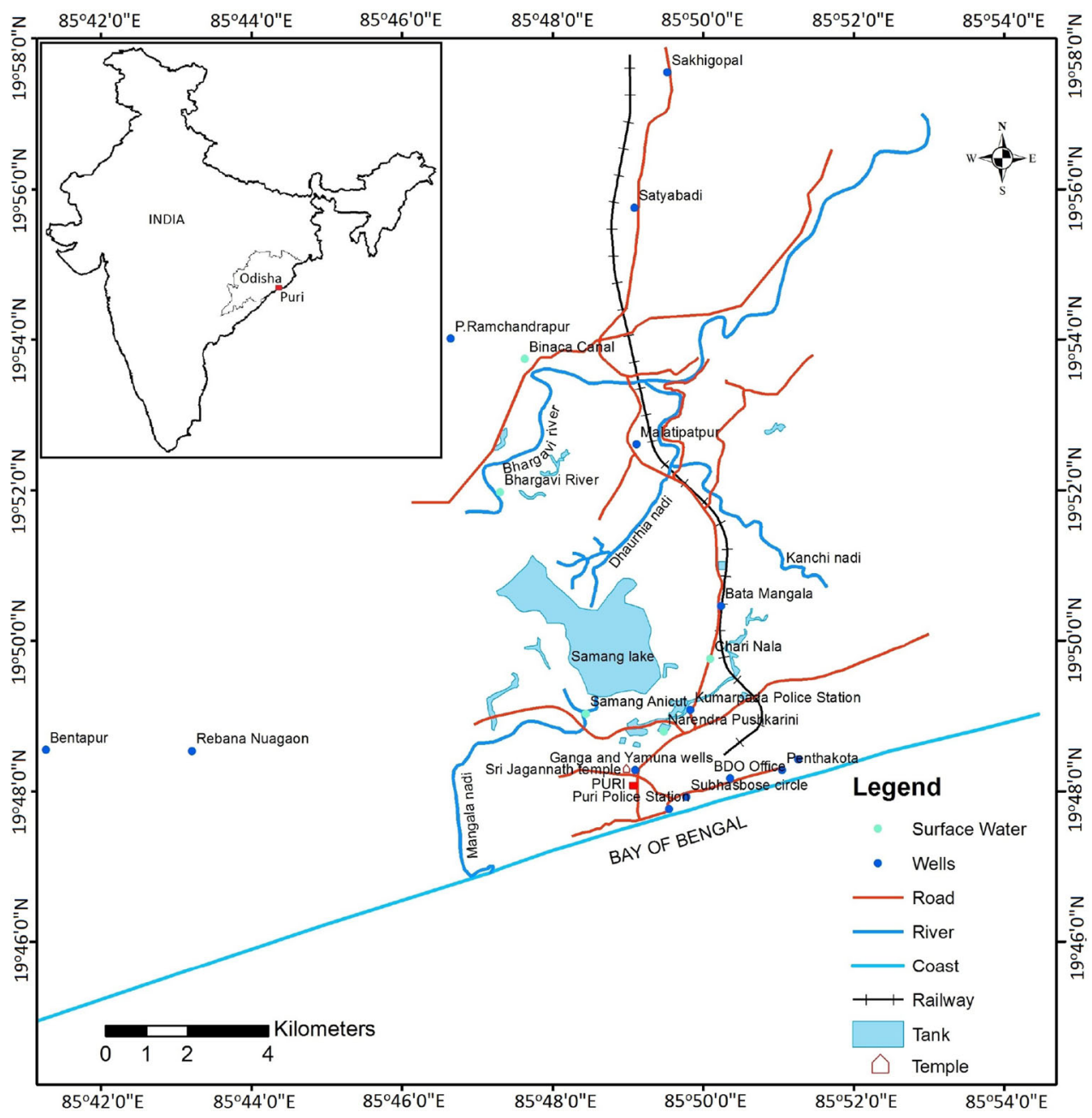

of Odisha state. Administratively, the town of Puri is divided in 30 wards with the major population concentrated around the famous temple of Jagannath. Geographically, the Puri town is abounded by the sea on the south, Bhargavi river in the north, Mangala River in the west, and Baligkhanda reserved forest in the east. The town is connected by broad gauge railway line to most part of the country. City is very old with history dating back to 3rd Century BC. Puri got prominence when the ruling kings built Shree Jagannath temple. The present temple was built in 12 th Century AD. Puri was declared a town on 19 January 1865 and Municipality on 1 April 1881. Present day town within Municipality limits spread over $16.84 \mathrm{~km}^{2}$ and Puri is considered a holy place.

\section{Population and tourist visit}

The population of the Puri city district as per 2001 census data is $1,25,199$. Population is estimated to be $1,86,000$ in 2008. As per 2011 census, population has increased to 201,026 with male population of 96,759 and female population of 104,267 in 2011 . The town resident population is growing exponential since 1941 and has not stability yet through land available is restricted. Devotees and tourists come to Puri all round the year. They offer prayer, enjoy the pristine beauty of sea, and relax. Over the years floating population is increasing. Average number of tourists visiting the town per day is 15,000 . Estimates suggest that people visiting Puri on Car festival day (a festival celebrated each year on a pre specified day) reach a peak of 1.0 million. Visitors during car festival recorded in 1841, 1892, and 1901 were $0.112,0.2$, and 0.3 million, respectively. In year 2008 and 2014 on car festival day, about 0.8 and 1 million people visited Puri. The coast line of the town is about $6.59 \mathrm{~km}$ along. Many star hotels have been constructed in recent years by private entrepreneurs along the beach boosting tourism.

\section{Climate}

The area enjoys a subtropical humid climate characterized by three distinct seasons-summer, winter, and rainy. The winter season starts from November and continues till mid- 
February. The summer season lasts till first week of June. The rainy season starts from the second of June and continues till September. May is the hottest month and December the coldest. Maximum temperature goes up $37-14^{\circ} \mathrm{C}$, in the winter. The climate of Puri in summer is warm and humid with average maximum and minimum temperature of 37.5 and $27{ }^{\circ} \mathrm{C}$, respectively. The climate in winter is cool and pleasant with average maximum and minimum temperature 28.2 and $15.2^{\circ} \mathrm{C}$, respectively. About $74 \%$ of the rainfall is received during monsoon season from June to September. Maximum precipitation occurs in July On average, there are 71 rainy days in year. The normal rainfall of the district is $1449 \mathrm{~mm}$, whereas received more than $1554 \mathrm{~mm}$ of rainfall during 2001 from the southern monsoon. About $74 \%$ of the annual rainfall is received from June to September. During 1991 the Puri block received maximum rainfall of $3410 \mathrm{~mm}$. The rainfall data are presented in Table 1. The relative humidity is generally high throughout the year, and at Puri, it varies from 62 to $85 \%$. The mean monthly potential evapotranspiration values ranges from $57 \mathrm{~mm}$ in January to $254 \mathrm{~mm}$ in May.

\section{Urban hydrogeology}

Puri which is one of the coastal towns Eastern India is known all over the world as an important centre of pilgrimage and an enchanting beach. Over thousands of pilgrims and tourists visit the town every year. Initially, the human settlement started around the temple of Lord Jagannath. Inhabitations were improperly planned and connected with narrow lanes. Over the years, the town has grown all around the temple and speeded in all directions. The town is underlain by unconsolidated alluvial formation of recent age. The coastal sand dune occurs almost parallel

Table 1 Monthly rainfall, temperature, and potential evapotranspiration in delta irrigation command stage (mean of 10 years)

\begin{tabular}{lclc}
\hline Months & Rainfall $(\mathrm{cm})$ & Mean temperature $\left({ }^{\circ} \mathrm{C}\right)$ & PET $(\mathrm{cm})$ \\
\hline January & 1.39 & 21.8 & 5.69 \\
February & 2.68 & 25.1 & 9.57 \\
March & 1.52 & 27.8 & 16.24 \\
April & 3.05 & 29.8 & 22.96 \\
May & 7.68 & 30.1 & 30.15 \\
June & 21.46 & 30.1 & 25.37 \\
July & 33.14 & 28.6 & 20.54 \\
August & 30.85 & 25.5 & 19.6 \\
September & 28.69 & 28.8 & 18.2 \\
October & 15.72 & 28.1 & 16.5 \\
November & 5.23 & 25.8 & 10.74 \\
December & 0.63 & 22.6 & 6.39 \\
\hline
\end{tabular}

to the shoreline and the width varies from $100 \mathrm{~m}$ to $7 \mathrm{~km}$. The lower deltaic plains occur adjacent to the coastal sand dunes and width varies from 5 to $10 \mathrm{~km}$. Extensive agriculture has been observed around Puri town in the deltaic plains. The sand and gravel layers form the prolific aquifers which are interconnected. The depth of dug wells varies from 5 to $15 \mathrm{~m}$ and depth to water level ranges from 1.0 to $12 \mathrm{mbgl}$. The geographical logging reported the presence of fresh water aquifer up to $42 \mathrm{~m}$ depth and then from 210 to $244 \mathrm{~m}$ depth. Old town of Puri which is a cluster of residential colonies, small temples and dharmasalas surrounding the famous temple of lord Puri Jagannath is situated on sand dunes. The ground slope is from east northwest to east southeast.

\section{Water supply to Puri town}

In the absence of any major surface water source, groundwater from is the only alternative for water supply to Puri town. The raw water for domestic supply to the town is presently being augmented from the two groundwater well fields located at the eastern and western boundaries of the town apart from other deep tube wells and hand pumps located at various places. Details of water supply from various systems are given in Table 2 .

\section{Methodology}

\section{Stable isotope characterization}

A network of dug wells and hand pumps is established for collection of groundwater water samples. In addition, surface water samples from canal and water bodies have also been collected. The field investigations like geo-hydrological studies, sampling for quality, and isotope analysis were undertaken in and Puri city. Hydrological investigations were conducted to collect water samples from about 21 locations well (Fig. 1) spread all over the study area. The water samples of river water, canal water, tank water, and groundwater were collected during March 2010. Efforts were made to avoid any contamination, evaporation, and effect of exchange with atmosphere. The procedure of sampling water for deuterium and oxygen-18 analyses is very simple. A very small amount of sample is enough. However, to be on safer side and for repeated measurements, a minimum of $20 \mathrm{ml}$ sample is collected in a HDPE bottle. While collecting samples, groundwater from tube wells and hand pumps water was left for sufficient time, so that the sample represents groundwater of the aquifer understudy. The sample bottles were sealed with wax and transported to laboratory for isotopic analysis. The physical properties of water are measured in situ. The 
Table 2 Details of daily supply of water in Puri city

\begin{tabular}{lll}
\hline 1 & From Balipanda-Tota Gopinath supply system & 8 MLD \\
2 & $\begin{array}{l}\text { From Chakra Tirtha to Markandeswara tank } \\
\text { supply system }\end{array}$ & 7 MLD \\
3 & From Ghoda Bazar supply system & 5 MLD \\
4 & Individual industrial sources & 2.5 MLD \\
5 & Hand pumps (504 nos.) & 3.5 MLD \\
& Total & 26 MLD \\
\hline
\end{tabular}

samples were analyzed for $\delta \mathrm{D}$ (hydrogen isotope- ${ }^{2} \mathrm{H}$ ) and $\delta^{18} \mathrm{O}$ (oxygen isotope) stable isotopes using continuous flow isotope ratio mass spectrometer and dual inlet isotope ratio mass spectrometer available at the National Institute of Hydrology (NIH), Roorkee. The measured error in estimates is $\pm 0.1 \%$ in $\delta^{18} \mathrm{O}$ and is $\pm 1.0 \%$ in $\delta \mathrm{D}$. The standards of measurement for stable isotopes are at the zero pivot points. Samples containing a greater proportion of the heavy isotopes have positive $\delta$ values; Samples with smaller $R$ value than the reference have negative $\delta$ values with respect to the reference. Isotope characteristics of precipitation collected at Kakinada in India which also gets most of the precipitation during south-west monsoon and from weather systems of Bay of Bengal are adopted. The same isotopic characteristic of precipitation is considered as representative of local precipitation of the study area.

\section{Meteoric water lines}

Water and solutes found in various segments of the hydrological cycle or the same segments during different seasons or under different climatic conditions would show useful variation in their concentrations because of the isotope fractionation process. One can notice measurable differences in isotopic character, and reasonable explanations are at hand for such observation of variations in the nature. Dansgaard (1964) conducted one of the earliest studies of the $\delta^{18} \mathrm{O}$ in precipitation. Here, $\delta$ value is the most common way to express the difference in isotopic composition between a sample and a reference with a ratio of $R$ value, which is a reference standard for the substance. This difference is most commonly expressed in terms of parts per thousand or permil (\%) and is symbolized by $\delta$. The relation between $\delta \mathrm{D}$ and $\delta^{18} \mathrm{O}$ that has been observed in global precipitation is expressed mathematically by the equation known as global meteoric water line (GMWL).

$\delta \mathrm{D}=8 \delta^{18} \mathrm{O}+10$.

The relation between $\delta \mathrm{D}$ and $\delta^{18} \mathrm{O}$ can be written in a standard form as a linear equation

$\delta \mathrm{D} \%=A \delta^{18} \mathrm{O}+d$, where $A$ is the 'slope' and $d$ is the 'intercept' or 'D excess' of $\delta \mathrm{D}$ vs $\delta^{18} \mathrm{O}$ line of fresh global meteoric waters. One can develop regional and local meteoric water lines on the pattern of standard relationship between $\delta \mathrm{D}$ and $\delta^{18} \mathrm{O}$ valid on regional or local levels.

\section{Deviation in meteoric water line}

A complicating factor for deviation in meteoric line is the cloud formation and precipitation. During cloud formation and during precipitation, droplets becomes sufficiently large in descent and they may evaporate and exchange water molecules with the air below the clouds. Low-level moisture may be isotopically distinct from upper level moisture. In addition, on its way down through the air, the droplet is likely to encounter air with the humidity less than $100 \%$. Thus, evaporation from the droplets occurs which is a fractionating process. Thus, the first precipitation droplet to fall through dry air is likely to show kinetic isotopic enrichment. Their values would fall to the right of the global meteoric line. Indian Meteoric Water Line is

$\delta \mathrm{D}=8.2 \delta^{18} \mathrm{O}+9.8 \%$.

The other process that can move waters to the right of meteoric line is oxygen isotope exchange with carbonate or silicate rocks. Water can have a varied history, including oxygen fractionation, between various types of rocks at significant depths in the earths crust. Waters discharged from volcanoes and hot springs help us to study directly the isotopic composition of deep geothermal waters. Craig (1961) demonstrated through oxygen and hydrogen isotopic determination that the majority of hot springs are dominated by meteoric water. According to Gibson et al. (2003), models developed.

\section{Groundwater flow model}

The groundwater modeling has been performed using Visual MODFLOW 2.1 version. MODFLOW is the US Geological Survey modular finite-difference based flow model that solves the groundwater flow equation. The program is used to simulate the flow of groundwater through aquifers. The governing flow equation for three dimensional saturated flow in saturated porous media is:

$$
\frac{\partial}{\partial x}\left(K_{\mathrm{x}} \frac{\partial h}{\partial x}\right)+\frac{\partial}{\partial y}\left(K_{\mathrm{y}} \frac{\partial h}{\partial y}\right)+\frac{\partial}{\partial z}\left(K_{\mathrm{z}} \frac{\partial h}{\partial z}\right) \pm Q=S_{\mathrm{s}} \frac{\partial h}{\partial t},
$$

where $K_{x}, K_{y}$, and $K_{z}=$ hydraulic conductivity along the $x$, $y$, and $z$ axis which are assumed $(\mathrm{m} / \mathrm{s}) ; h=$ piezometric head $(m) ; Q=$ volumetric fluxper unit volume representing source/sink terms; $S_{\mathrm{s}}=$ specific storage coefficient 
defined as the volume of water released from storage per unit change in head per unit volume of porous material.

The different input layers, i.e, recharge, boundary conditions, well locations, and hydraulic conductivity, have been input and created a model in Visual MODFLOW Package for the Puri study area. Collected data have been used as an input for MODFLOW model. Boundary conditions, river, drain, wells were well data based in the model. The different boundary conditions used in the groundwater model, such as no flow in the western side, constant head of Samang Lake part, and the part of Bhargavi River, and drains have been marked for the respective areas for groundwater flow modeling. The groundwater contour map has been obtained for the larger area than the study area from the Central Ground Water Board, Odisha, Bhubaneswar. The NIH (Tyagi et al. 1993, 1995) case studies' reports analyzed for defining the model boundary. As per the map, flow direction is from north-west to south and south east side of the study area. Some part of the west boundary is defined by the no flow boundary and Samang lake area as constant head boundary to accommodate the incoming groundwater from north direction (Fig. 1). The topography of the study area is very flat due to the coastal alluvium plain. The elevation of the top surface in the study area varies from 25 to $0 \mathrm{~m}$. Adjusting the top and bottom surfaces in the model is a difficult task and accuracy of the results of the model depends upon the accuracy of the layer. Krigging method has been used for interpolation, and accuracy of the DEM near the ponds has been improved by giving more points for interpolation. Intensive work has been carried out to define the top surface of the study area, and SRTM data were used in digitization of surface contours and verified with maps procured from district open series maps of survey of India. The bottom surface has been assumed as sandy alluvium as the study team enquired form State Groundwater Department, Odisha, Bhubaneswar.

\section{Results and discussions}

\section{Groundwater quality analysis}

The hydro-chemical analysis results of groundwater, surface water collected in and around Puri city, and sea water samples collected from Bay of Bengal during the month of March and November 2010. Total 21 samples were collected and analyzed for various physical and chemical parameters, like $\mathrm{pH}$, electrical conductivity, Total dissolved solids, total hardness, total alkalinity, calcium, magnesium, sodium and potassium, and anions, such as chloride, bicarbonate, sulphate, and nitrate, for ascertaining the potability of water. The range of $\mathrm{pH}$ during the surveys is 7-8.4 in pre-monsoon and 7.3-8.25 in post-monsoon period. As a whole, the $\mathrm{pH}$ of the water samples is within the range of potability. The range of conductivity in the pre-monsoon period is ranging between 231 and 2710 $\mu \mathrm{mhos} / \mathrm{cm}$, and in post-monsoon period, it is 260-1690 $\mu \mathrm{mhos} / \mathrm{cm}$. Most of the wells in the study area are fit for drinking only the water at P. Ramachandrapur is slightly exceeding the limits. The samples collected from Ganga and Jamuna well in Jagannath Temple are reported to be excellent waters and having good taste as well. A total dissolved solid is an indication of the overall chemicals/ ions present in the water sample and their amount decides the taste/salinity or health of the water. Except at P. Ramachandrapur, almost all wells are within the range of drinking water standards. For a good drinking water, the TDS value may be around $500 \mathrm{mg} / \mathrm{l}$. The variation of TDS in and around Puri city is presented in Fig. 2. The presence of carbonates, bicarbonates, and hydroxides is the most common cause of alkalinity in natural waters. The minimum and maximum alkalinity in the pre-monsoon ranges from 136 to $592 \mathrm{ppm}$, and in post-monsoon, it ranges from 148 to $714 \mathrm{ppm}$. All the wells are satisfying the standard range except at $\mathrm{P}$. Ramachandrapur. The range of sodium in the samples during pre-monsoon period is $16-360 \mathrm{ppm}$, and in post-monsoon, it varies between 9 and $160 \mathrm{ppm}$.

Total hardness is due to the presence of Calcium and Magnesium ions. The range of calcium content during March 2010 is between 18 and 88 ppm, and in November 2010 , it is in the range of $20-88 \mathrm{ppm}$ and magnesium content is between 8 and 83 ppm in March and 12-64 ppm in November 2010. In general, both the ions are within the limits in most of the wells, and overall, it is satisfying both the ions. Calcium and magnesium along with their carbonates, sulphates and chlorides make the water hard, both temporarily and permanently. The total hardness ranges between 80 and 540 ppm in March and 97-481 ppm in November 2010. As the water at P. Ramachandrapur is again exceeds the limits and showing high values of hardness. Most of the wells are showing overall hard water. Mainly, chloride content is important for taste consideration. No adverse health effects on human have been reported from intake of waters containing even higher concentration of chloride. The chloride content in the waters varies between 20 and 548 ppm in March and 44-212 ppm in November 2010 with higher values at P. Ramachandrapur.

Sulphate content more than $150 \mathrm{mg} / \mathrm{l}$ is objectionable for many domestic purposes. Water containing more than $500 \mathrm{ppm}$ sulphate tastes bitter and it has purgative effect beyond $1000 \mathrm{ppm}$. The sulphate content in the study area varies between 4 and 216 ppm in March and 4-87 ppm in November 2010. Again, well at P. Ramachandrapur has the higher limit of the sulphate. Nitrate is effective plant 
Fig. 2 Spatial plot showing TDS in and around Puri city

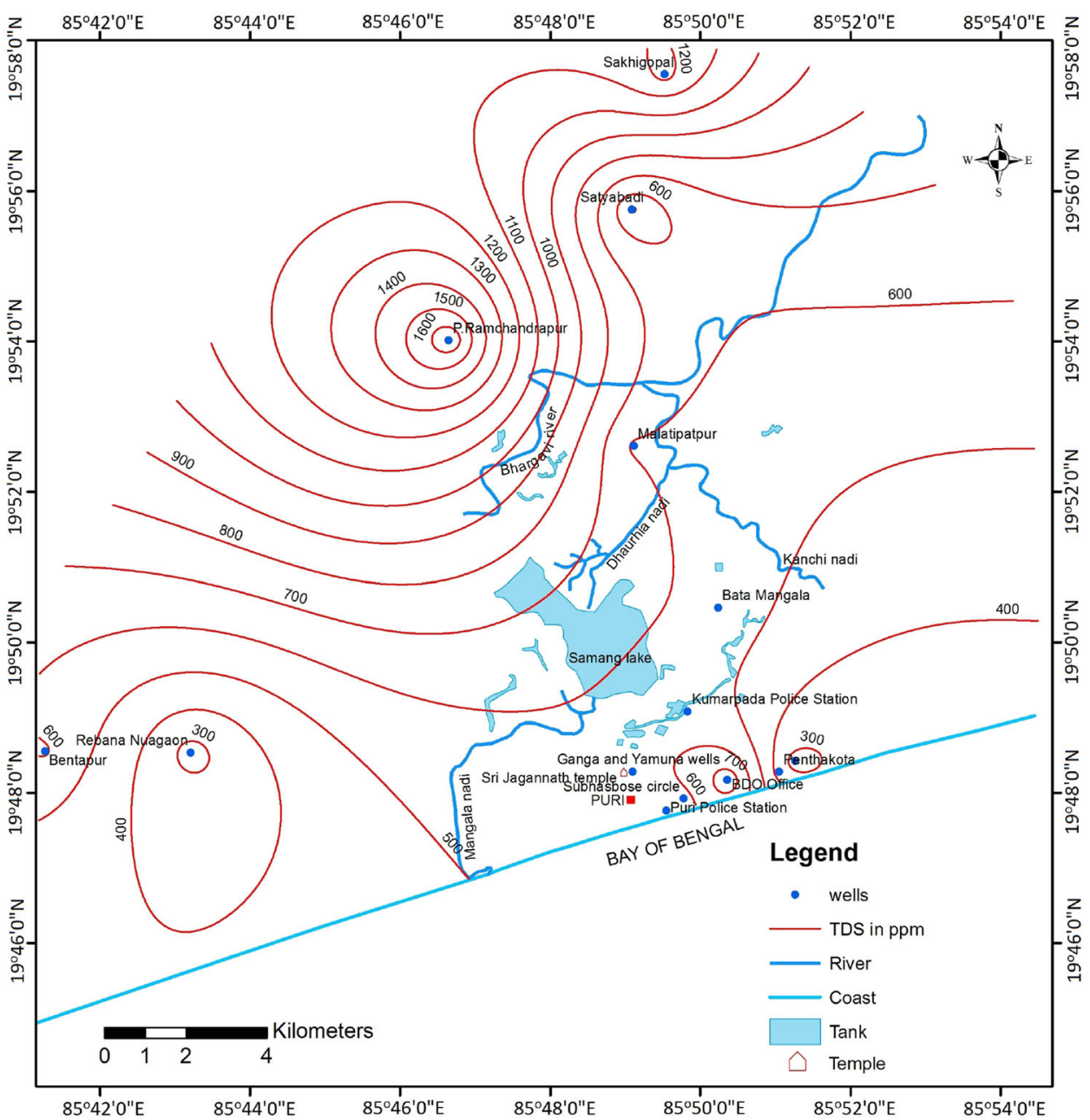

nutrient and moderately toxic. Its concentration above $45 \mathrm{mg} / \mathrm{l}$ in drinking water may prove detriment to human health. The nitrate value in the study area ranges between 0 and $118 \mathrm{ppm}$ in March and 0-134 ppm in November 2010. Excess nitrates may influence only the infants by reducing the hemoglobin in the blood of the infants.

After considering the above all parameters and the overall chemistry of the waters in and around Puri city, both surface and groundwater are suitable for drinking. Only, the well at $P$. Ramachandrapur is showing adverse values and may not be suitable for drinking purpose. The wells located in the Jagannath temple, namely Ganga and Jamuna, are having good quality of waters, even though there are slight differences in the parameters. The variations of the parameters in the samples between pre-monsoon and post-monsoon are due to dilution of the samples during the monsoon period. The concentrations will go down due to mixing of rain water with the ground or surface waters in the monsoon and reflects in the post-monsoon samples.

\section{Isotope analysis}

The $\delta \mathrm{D}$ vs $\delta^{18} \mathrm{O}$ plot for Regional MWL and best-fit lines for river water, canal water, and ground water, in the study period of the study area is presented in Fig. 3. The 'slope' and 'D excess' or 'intercept' of best-fit lines of different types of water is shown in tabular form in Table 3. On regional scale, the results indicate that the slope of GWL of dug wells is 4.56 and hand pumps is 5.80 and is less than that of MWL south India, i.e., 7.82, river water and canal water, i.e., 7.77. This shows residual liquid water that has undergone evaporation and plots to the right of the meteoric water line. GWL of hand pumps shows less evaporation effects than dug wells. The intercept of GWL for dug wells is -9.33 and for hand pumps is -5.02 , and is less than that of Regional MWL, i.e., 10.22, river and canal water, i.e., 6.24. This also indicates that the recharge conditions to groundwater are almost constant. 


\section{Surface water and groundwater interaction}

The surface water and groundwater interaction may be studied by groundwater modeling, channel water balance, isotope mass balance method, and/or by statistical method using the river and groundwater-level fluctuation data. The statistical method based on Darcy's law involves analyses of the river water levels and groundwater levels adjacent to the river. Here, procedure isotope mass balance method is dealt briefly.

The approach is based on the fact that if the rivers originates at higher altitudes and has a different stable isotopic composition than that of groundwater that is recharged by infiltration of local precipitation, then stable isotopes can be used to understand river and groundwater interaction. In most of the cases, the stable isotope ${ }^{18} \mathrm{O}$ is utilized for determining the contribution of groundwater to the river flow. For example, the isotopic balance and mass balance equations of an admixture of rainwater and groundwater in a stream can be written as

$\mathrm{mg} \cdot \mathrm{Rg}+\mathrm{mr} \cdot \mathrm{Rr}=\mathrm{Ram}$,

and

$\mathrm{mg}+\mathrm{mr}=1$,

where $\mathrm{Rg}$ and $\mathrm{Rr}$ are the isotopic composition of the groundwater and the river water, respectively, and $\mathrm{mg}$ and $\mathrm{mr}$ are the fractions of ground water and river water, respectively; in the admixture, Ram is the isotopic composition of the admixture.

From the above two equations, we have

$$
\begin{aligned}
& \mathrm{mr}=(\operatorname{Ram}-\mathrm{Rg}) /(\mathrm{Rr}-\mathrm{Rg}), \\
& \mathrm{mg}=(\operatorname{Ram}-\mathrm{Rr}) /(\operatorname{Rg}-\mathrm{Rr}) .
\end{aligned}
$$

Therefore, by knowing the value of $\mathrm{Rg}, \mathrm{Rr}$, and $\mathrm{Ram}$, the fraction of river water mixed with ground water can be evaluated. The $\delta^{18} \mathrm{O}_{16}$ values of different types of waters in and around Puri city are shown as graph plot and in tabular form are depicted in Fig. 4. The values of $\delta{ }^{18} \mathrm{O}_{16}$ for precipitation are taken as those for Kakinada city, and for the river or canal water, these are taken at Binaca canal and Samang lake to evaluate the composition of precipitation and canal or river water in the groundwater at dug wells and tube wells in the study area.

The contribution of recharge from precipitation or rainfall and canal water is estimated using ${ }^{18} \mathrm{O}$ values at all dug well and hand pump location of the study area to understand the dominating factor of recharge source using the mass balance approach and the results are presented in Table 4. The areal extent of influence of recharge from precipitation to the groundwater in and around Puri city is shown in Fig. 5 as rainfall-recharge contour plot. Similarly, the areal extent of influence of recharge from river and canal water to the groundwater in the study area is shown in Fig. 6 as surface water recharge contour plot. It is evident from Fig. 5 that the temple wells Ganga and Jamuna are predominantly recharged from precipitation. Due to rapid urbanization of the Puri city, the recharge to wells is influenced adversely by not only due increase in pumping of groundwater but also due to reduction in uncovered or open recharge area like green belt and vegetation and land use or cover change towards increasing residential and commercial built up areas. Hence, the recharge to temple well can be enhanced not only by regulating over exploitation of groundwater areas around the temple complex, but also by increasing rainfall recharge by taking up artificial recharge systems do divert excess runoff from rooftops and paved areas around the temple complex.
Fig. 3 Stable isotope characterization and best-fit line for $\delta \mathrm{D}$ vs $\delta^{18} \mathrm{O}$ for different water samples in and around Puri city

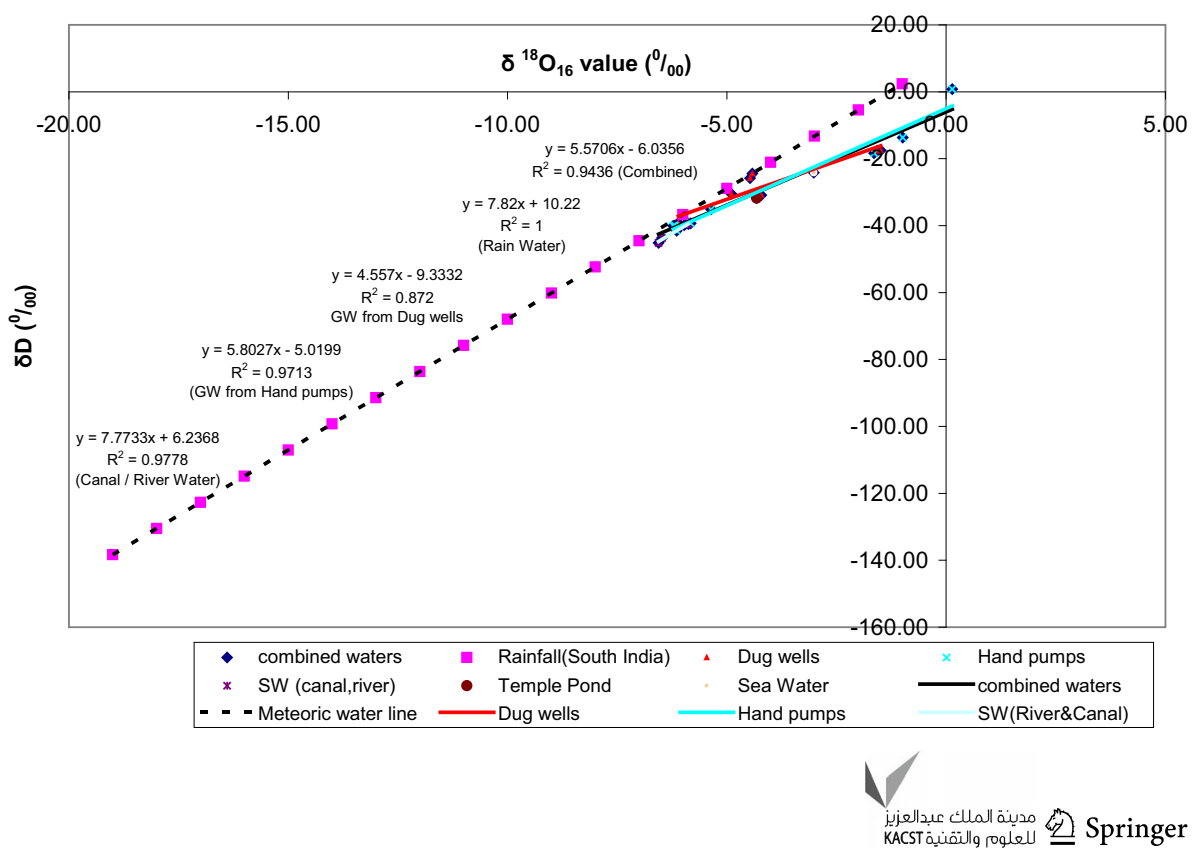


Table 3 Slope and intercept of best-fit line of different water samples of the study area

\begin{tabular}{lccccc}
\hline & Combined waters & Precipitation (South India) & Groundwater dug wells & Groundwater hand pumps & River and canals \\
\hline Slope & 5.57 & 7.82 & 4.56 & 5.80 & 7.77 \\
D excess or intercept & -6.04 & 10.22 & -9.33 & -5.02 & 6.24 \\
\hline
\end{tabular}

Fig. 4 Variation of $\delta^{18} \mathrm{O}_{16}$ for different water samples in and around Puri city

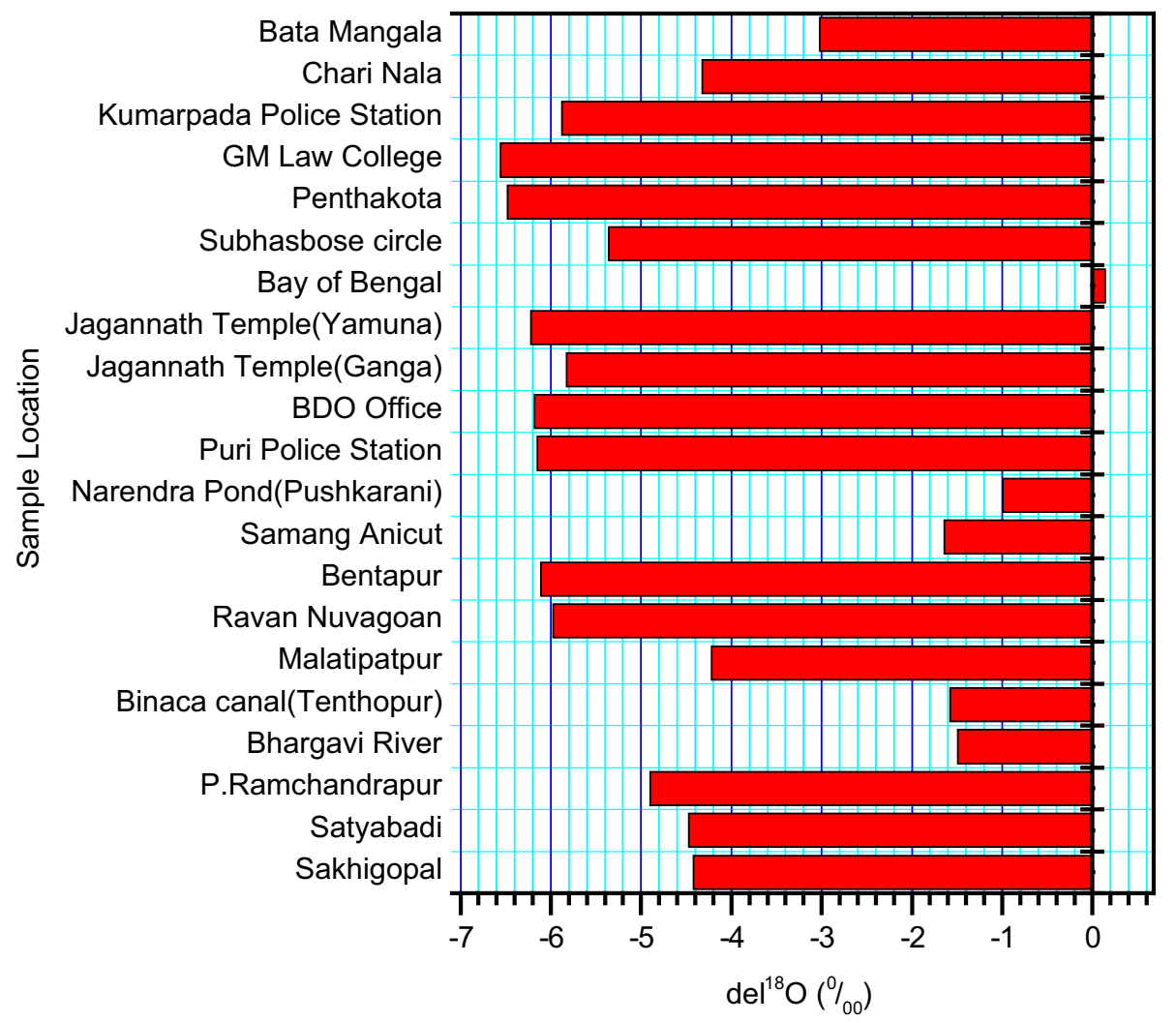

\section{Groundwater flow analysis}

A previous study of Central Groundwater Board (Roy 2004) has been used to identify the land use/land cover of the study area. The soil and land-use/land cover property of the area have been used to delineate the recharge polygons and to mark the recharge areas. Rainfall, river discharges are the main sources of groundwater recharge in this area. Average annual recharge values of $250 \mathrm{~mm} /$ year is used for the model. The study area falls in coastal alluvium; clear demarcation of the boundary is limited up to groundwater table depth. The study area falls within the drain in north-west direction (Dhauriha nala), north-east (Kanchi nala), and Bay of Bengal in south. Extensive field investigation has been carried out in the study area and interacted with field department to obtain most of the parameters used in MODFLOW. Conductivity has been collected from the previous published papers and literature (Mohapatra 2011) having values as $K_{x}(0.005 \mathrm{~m} /$ day $), K_{y}$ $(0.005 \mathrm{~m} /$ day $)$, and $K_{z}(0.0005 \mathrm{~m} /$ day $)$. The map of recharge zones which is made by soil and land-use map of the study area is either scrubby or under rice cultivation consists of sandy soil with the agriculture and fallow land type land use. The urban area with buildings and concretized roads reduced the recharge and increased usage due to inflow of tourists. Hydraulic parameters of the previous studies reported by Singh et al. (2002) are taken into consideration during model calibration. The major part of the study area is covered by alluvium, which is covering $70 \%$ part of the study area and composed of sandy, forms the principal and potential confined aquifers. The thickness of the alluvium varies from 80 to $120 \mathrm{~m}$ in different parts of the study area. The bore wells are the only source to fulfill domestic demands of this area. Data related to pumping wells have been collected by local administrative authority. Average discharges from the pumping wells have been found in the range of $2000 \mathrm{~m}^{3} /$ day. Due to the presence of illegal pumping wells and insufficient data, total water consumption has also been calculated by other methods reported by Mohapatra (2011). 
Table 4 Contribution of canal water and precipitation in the groundwater

\begin{tabular}{llllll}
\hline Well location & $\begin{array}{l}\text { Canal } \\
\text { influence }(\%)\end{array}$ & $\begin{array}{l}\text { Precipitation } \\
\text { influence }(\%)\end{array}$ & Well location & $\begin{array}{l}\text { Canal } \\
\text { influence }(\%)\end{array}$ & $\begin{array}{l}\text { Precipitation } \\
\text { influence }(\%)\end{array}$ \\
\hline Sakhigopal & 47.3 & 52.7 & Ganga well & 22.6 & 77.4 \\
Satyabadi & 46.3 & 53.7 & Yamuna well & 15.2 & 84.8 \\
P. Ramchandrapur & 38.7 & 61.3 & Subhasbose circle & 31.2 & 6.5 \\
Malatipatpur & 50.9 & 49.1 & Penthakota & 9.5 & 89.5 \\
Ravan Nuvagoan & 19.3 & 80.7 & GM law college & 21.6 & 91.0 \\
Bentapur & 17.4 & 82.6 & Kumarpada police station & 50.4 & 78.4 \\
Puri police station & 16.6 & 83.4 & Chari Nala & 74.5 & 49.6 \\
BDO office & 15.9 & 84.1 & Bata Mangala & 25.5 \\
\hline
\end{tabular}

Fig. 5 Areal extent of influence of recharge from precipitation in the groundwater in and around Puri city

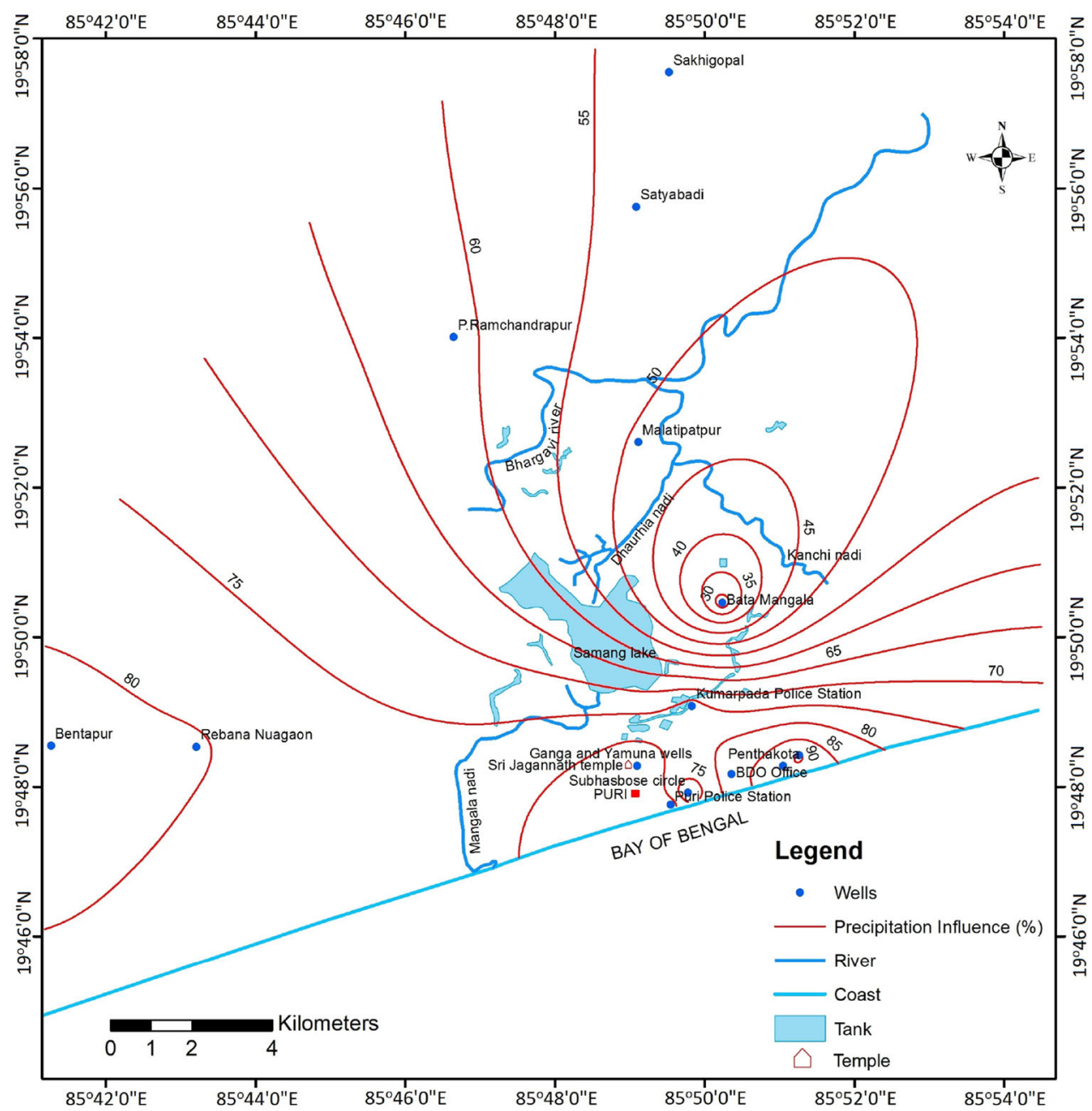

\section{Model calibration}

In this study, different model parameters are estimated independently to increase the model accuracy and this helps to reduce the importance for extensive calibration of the model parameters. Although calibration of the model has been performed by comparing the computed and observed values of groundwater head at different locations in the study area, the calibration of hydraulic conductivity parameter has been done in steady-state condition by modifying it in different zones. The model has been calibrated in the steady-state condition with the available data. The groundwater head developed by the steady-state condition has been taken as the initial head for transient run of model. The constant head boundary has also been calibrated in the steady-state condition to incorporate the 
Fig. 6 Areal extent of influence of recharge from river or canal water in the groundwater in and around Puri city

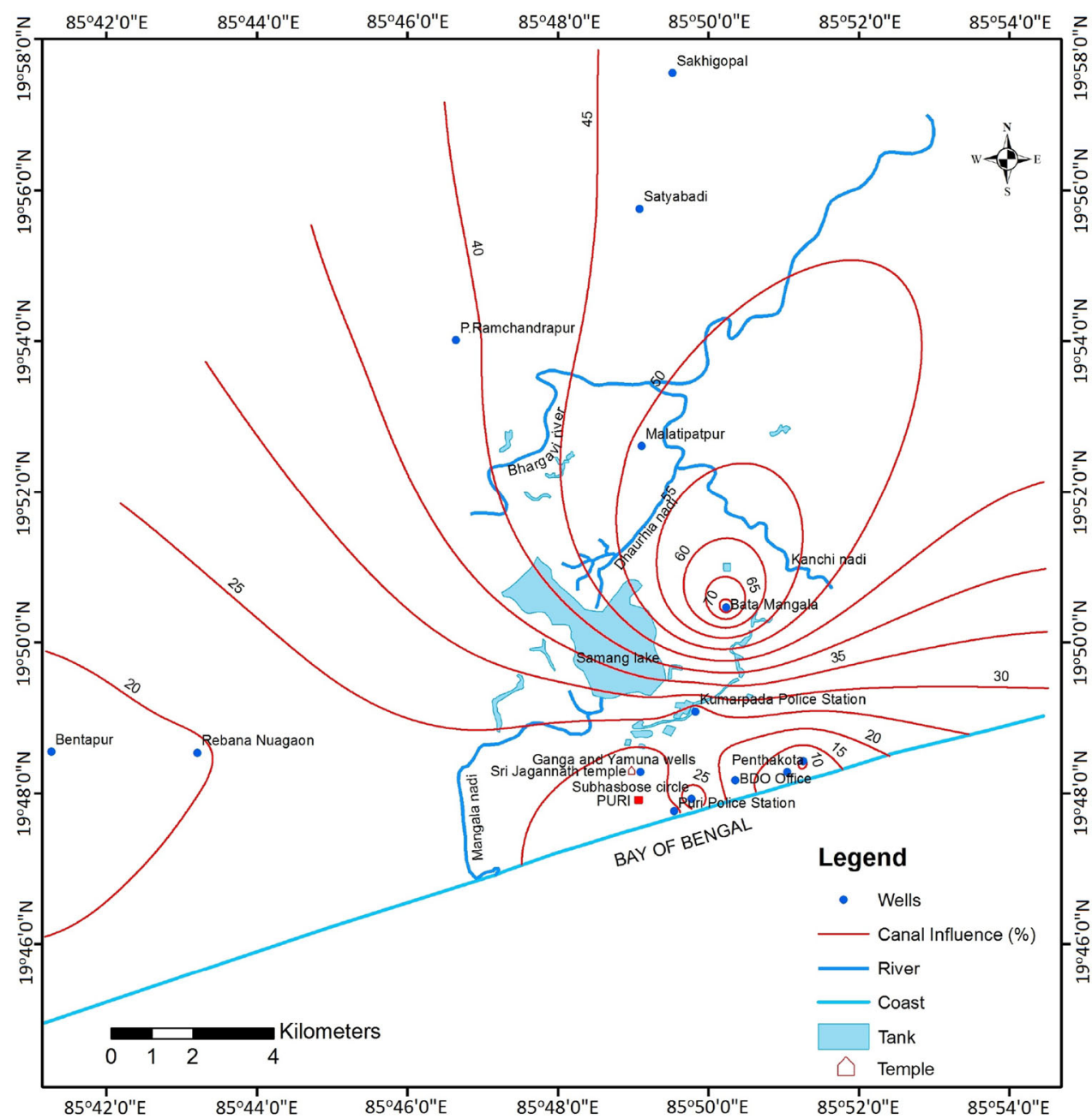

inflow from adjacent aquifer. The accuracy of the model could be understood with the grid size from $500 \times 500 \mathrm{~m}$. The head of constant head boundary has also been calibrated in steady-state condition. Figure 7 depicts the computed water level contour graph which is almost matching with the observed values of groundwater depth in steady-state condition. It may be noted that the observed groundwater level varies from 0.5 to $4.75 \mathrm{~m}$ in three different observation wells in the study area. Sensitivity analysis has been performed for the value of hydraulic conductivity. The calibrated value of hydraulic conductivity has been increased and decreased by $20 \%$, and its effect has been observed at the location of observation wells.

\section{Modeling scenarios}

A scenario has been developed to maintain water level in Samang Lake through river or canal flow that would be able to meet the demand at Chakratheerth pumping well that would provide water to the entire study area of Puri city completely. The effect of this scenario has been observed at evenly distributed different control points around the potential zones, including abstraction by Hotels. Effect of reduction of rainfall in terms of net recharge is also studied. The scenario has been developed using MODFLOW keeping head as $5 \mathrm{~m}$ at Samang lake and groundwater-level plots are depicted in Fig. 8. It may be noted that water spread area of Samang lake was $5.57 \mathrm{~km}^{2}$ as per 1972-1973 Survey of India map, and from our field investigation, it was found that water spread area during March 2010 has been reduced to less than $100 \mathrm{~m}^{2}$. The whole lake area has been converted into agriculture field. During rainy season, the entire lake area becomes over flooded and cropping activities are resumed only after flood recession. This may be another reason, as recharge area is drastically reduced by converting the lake area into agriculture activity as there is no water storage available during summer season; ground water flow is reduced towards Puri city. It is, therefore, recommended to restore Samang Lake and maintain water level so as to prevent more declination in groundwater level towards Puri city. Second scenario 
Fig. 7 Plot showing groundwater contour for computed water level

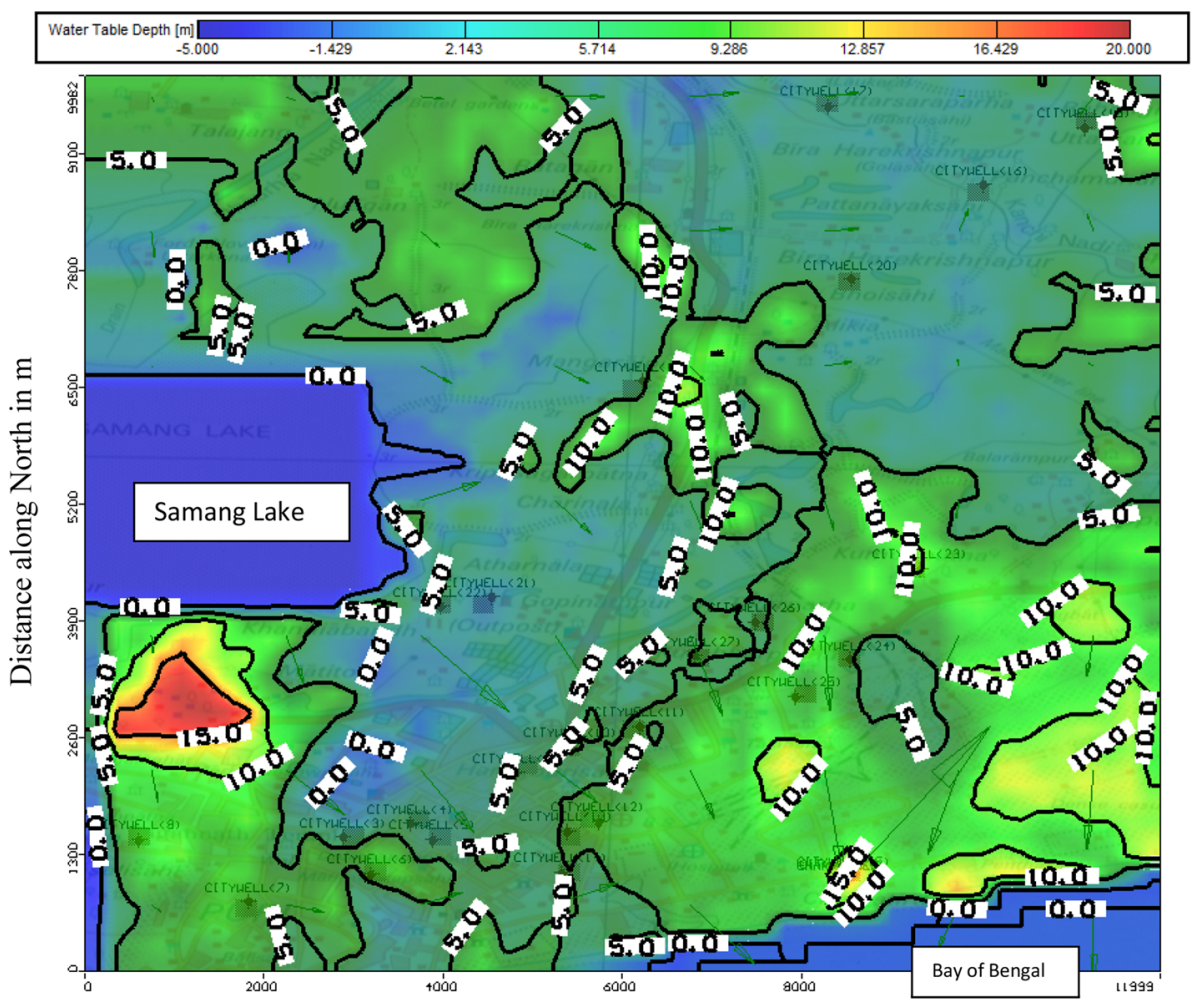

Distance along the East in $\mathrm{m}$ has been developed considering first scenario with heavy pumping rate of $2000 \mathrm{~m}^{3} /$ day in the wells within the study area, and computed flow direction is presented in Fig. 9. It is observed that due to heavy pumping, water table is declining by $4-6 \mathrm{~m}$ in the study area and continuous pumping may lead to sea water ingress. Therefore, it is essential to rejuvenate the Samang Lake and maintain water level, so that water would be available to Puri city.

\section{Conclusions}

This study investigates the causes of decreasing water level in two wells (Ganga and Yamuna) inside the Jagannath Temple in Puri city, India, which is engendering water scarcity for day to day temple activities. In the investigation, isotope analysis has been conducted followed by hydrochemical analysis to find out the recharge zone. The causes are studied by undertaking modeling study of rainfall-recharge processes, surface water-groundwater interactions, and increasing demands due to urbanization at basin scale. Hydrochemical analysis of groundwater samples indicates that $\mathrm{pH}$ value is varying from 7 to 8.4 in premonsoon and 7.3 to 8.25 in post-monsoon period and electrical conductivity (EC) is found in between 238 and $2710 \mu \mathrm{mhos} / \mathrm{cm}$. The EC values indicate that the shallow groundwater in Puri is not saline. Overall, chemistry of the waters in and around Puri city indicates that both surface and groundwater are suitable for drinking except well at P. Ramachandrapur which is exhibiting adverse values and may not be suitable for drinking purpose. Water quality analysis indicated that the wells located in the Jagannath temple testifying good quality of waters. To identify the groundwater source/s, isotopes like O-18, deuterium and water chemistry data have been analyzed. The stable isotopic signatures indicate that there are two different recharge sources active in the city area. It may be noted that most of the handpumps, water recharged by the surface water sources. From the current investigation, it is evident that in a few handpumps and most of the dug wells, isotopic signatures of water samples resembles with local precipitation. The groundwater recharge is taking place from the north-southern direction. Isotopic signature indicates that temple wells (Ganga and Jamuna) are predominantly recharged from precipitation. As a result of rapid urbanization, the recharge to wells is not only influenced adversely by increase in pumping of groundwater but also due to reduction in uncovered or open recharge area. It is recommended that the recharge to temple well can be enhanced by (1) regulating over exploitation of groundwater areas around the temple complex and (2) increasing rainfall recharge in and around the temple complex by taking up artificial recharge systems to divert excess runoff from rooftops and paved areas. Visual MODFLOW has 
Fig. 8 Plot showing groundwater-level (bgl) contour keeping $5 \mathrm{~m}$ head at Samang Lake

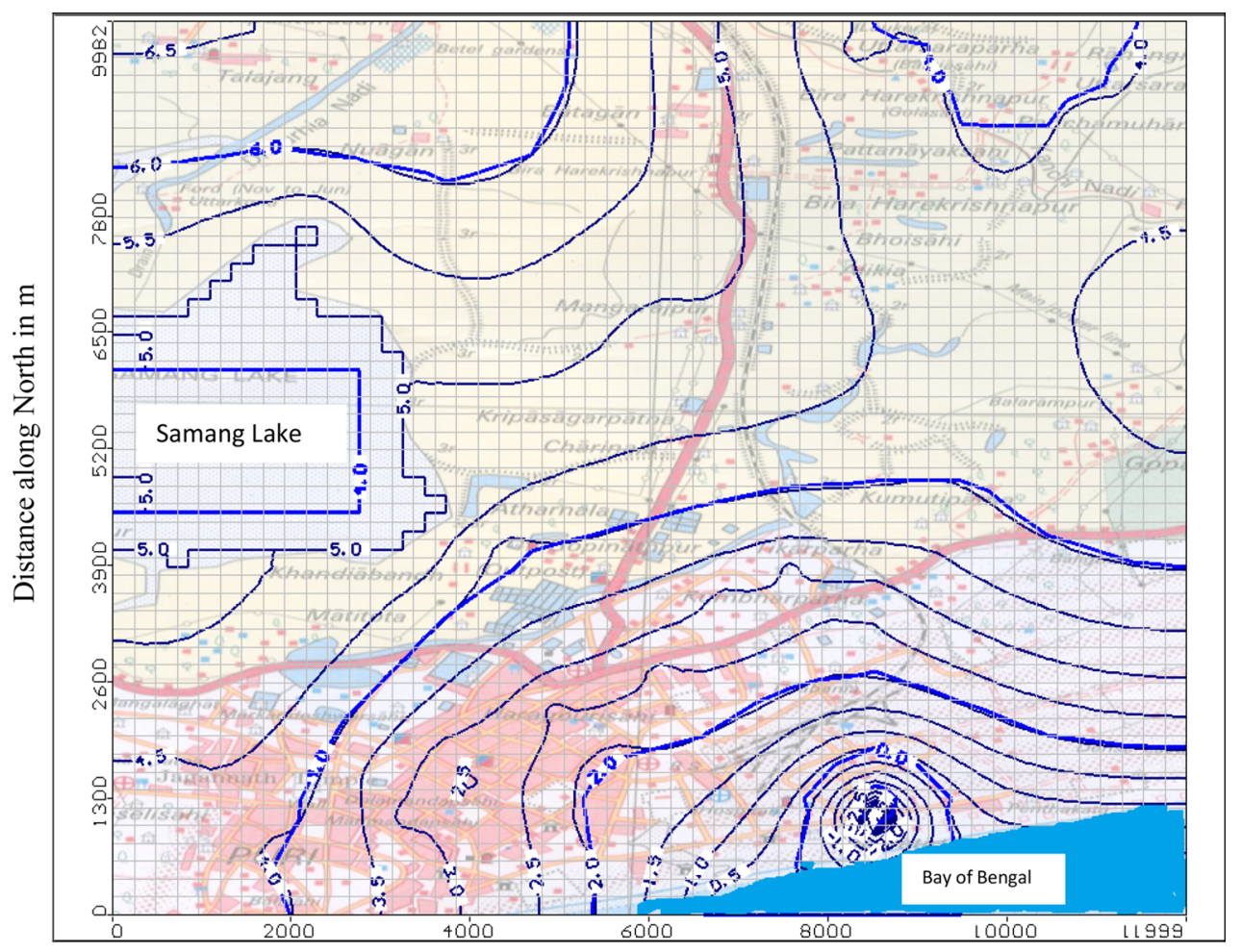

Distance along the East in $\mathrm{m}$

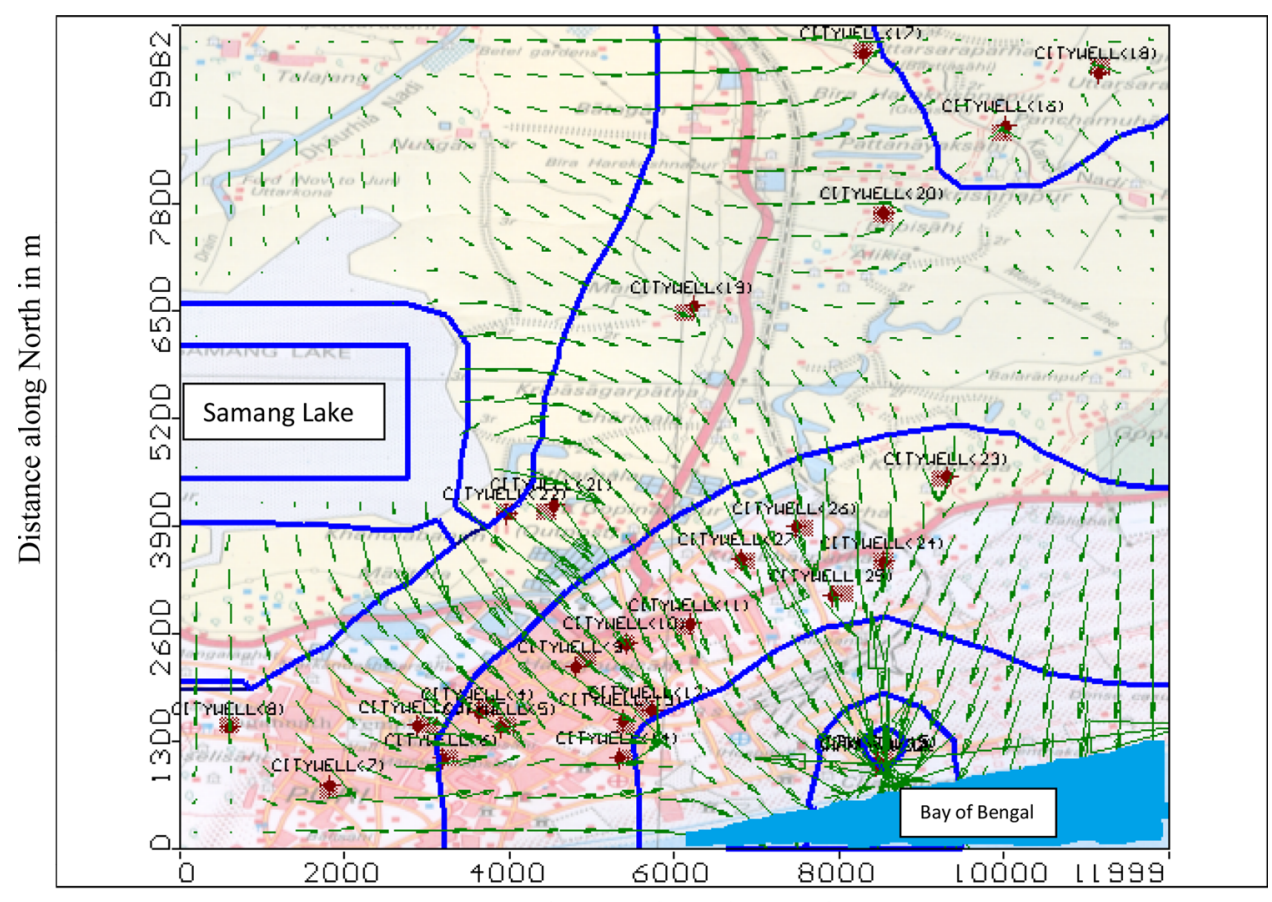

Distance along the East in $\mathrm{m}$
Fig. 9 Plot showing

groundwater flow direction due to heavy pumping $2000 \mathrm{~m}^{3} /$ day been used for studying groundwater aspects of Puri city. Different scenarios have been developed to understand groundwater condition in and around Puri city. It is found that groundwater flow takes place from north to south which resembles with isotopic signature. It is recommended to maintain water level in Samang Lake to restore depletion in groundwater level in Ganga and Yamuna wells. 
Open Access This article is distributed under the terms of the Creative Commons Attribution 4.0 International License (http:// creativecommons.org/licenses/by/4.0/), which permits unrestricted use, distribution, and reproduction in any medium, provided you give appropriate credit to the original author(s) and the source, provide a link to the Creative Commons license, and indicate if changes were made.

\section{References}

Ali KK, Al-Kubaisi QY, Al-Paruany KB (2015) Isotopic study of water resources in a semiarid region, western Iraq. Environ Earth Sci 74(2): 16711686

Alley WM, Emery PA (1986) Groundwater model of the Blue River basin, Nebraska-20 years later. J Hydrol 85:225-249

Al-Salamah IS, Ghazaw YM, Ghumman AR (2011) Groundwater modeling of Saq Aquifer Buraydah Al Qassim for better water management strategies. Environ Monit Assess 173(1-4):851-860

Athavale RN (1983) Injected tracers in studies on the unsaturated zone. In: Proc. workshop on hydrology. BARC, pp179-197

Babka B, Futó I, Szabó S (2011) Clustering oxbow lakes in the Upper-Tisza Region on the basis of stable isotope measurements. J Hydrol 410(1-2):105-113

Baldwin C, Tan P, White I, Hoverman S, Burry K (2012) How scientific knowledge informs community understanding of groundwater. J Hydrol 474:74-83

Batelaan O, Smedt FD (2007) GIS-based recharge estimation by coupling surface-subsurface water balances. J Hydrol 337:337-355

Blasch KW, Bryson JR (2007) Distinguishing sources of ground water recharge by using $\mathrm{d} 2 \mathrm{H}$ and $\mathrm{d} 18 \mathrm{O}$. Groundwater 45(3):294-308

Brock BE, Wolfe BB, Edwards TWD (2007) Characterizing the hydrology of shallow floodplain lakes in the Slave River Delta, NWT, Canada, using water isotope tracers. Arctic, Antarctic and Alpine Research 39(3):388-401

Brock Bronwyn E, Yi Yi, Clogg-Wright Kenneth P, Edwards Thomas WD, Wolfe Brent B (2009) Multi-year landscape-scale assessment of lake water balances in the Slave River Delta, NWT, using water isotope tracers. J Hydrol 379(1-2):81-91

Brooks KN, Ffolliott PF, Gregersen HM, DeBano LF (2003) Hydrology and the management of watersheds. Iowa State Press, Ames, p 574

Brutsaert W (2005) Hydrology: an introduction. Cambridge University Press, New York, p 618

Craig H (1961) Isotopic variations in meteoritic waters. Science 133:1702-1703

Dansgaard W (1964) Stable isotopes in precipitation. Tellus 16(4):436-468

Demlie Molla, Ayenew Tenalem, Wohnlich Stefan (2007) Comprehensive hydrological and hydrogeological study of topographically closed lakes in highland Ethiopia: the case of Hayq and Ardibo. J Hydrol 339(3-4):145-158

Dimitriou E, Tsintza P (2015) Hydrogeologic investigations in western Crete by using isotopic analyses and GIS techniques. J W Resour Prot 7:923-937

Gaur S, Chahar BR, Graillot D (2011) Combined use of groundwater modeling and potential zone analysis for management of groundwater. Int J Appl Earth Obs Geoinf 13:127-139

Gaura S, Chaharb BR, Graillot D (2011) Combined use of groundwater modeling and potential zone analysis for management of groundwater. Int J Appl Earth Obs Geoinf 13:127-139
Gibson JJ (2002) Short-term evaporation and water budget comparisons in shallow Arctic lakes using non-steady isotope mass balance. J Hydrol 264(1-4):242-261

Gibson JJ, Prepas EE, McEachern P (2002) Quantitative comparison of lake throughflow, residency, and catchment runoff using stable isotopes: modelling and results from a regional survey of Boreal lakes. J Hydrol 262(1-4):128-144

Gibson JJ, Aggarwal P, Hogan J, Kendall C, Martinelli LA, Stichler W, Rank D, Goni I, Choudhry M, Gat J, Bhattacharya S, Sugimoto A, Fekete B, Pietroniro A, Maurer T, Panarello H, Stone D, Seyler P, Mauricebourgoin L, Herczeg A (2003) Isotope studies in large river basins: a new global research focus. EOS 83(52):616-617

Groundwater Resource Estimation Methodology (GEC) (1997) Report of the groundwater resource estimation committee, Ministry of Water Resources, Government of India, New Delhi

Guo S (2002) Two-parameter monthly water balance model. In: Singh VP, Frevert DK (eds) Mathematical models of small watershed hydrology and applications. Water Resources Publications, Highlands Ranch, pp 113-166

Gupta SK (2010) Modern hydrology and sustainable water development. Wiley, Hoboken, p 464

Gurrieri JT, Furniss G (2004) Estimation of groundwater exchange in alpine lakes using non-steady mass-balance methods. J Hydrol 297(1-4):187-208

Isokangas E, Rossi P, Ronkanen A, Marttila H, Rozanski K, Kløve B (2015) Quantifying groundwater dependence of a sub-polar lake cluster in Finland using an isotope mass balance approach. Hydrol Earth Syst Sci 19:1247-1262

Jonsson Christina E, Leng Melanie J, Rosqvist Gunhild C, Seibert Jan, Arrowsmith Carol (2009) Stable oxygen and hydrogen isotopes in sub-Arctic lake waters from northern Sweden. J Hydrol 376(1-2):43-151

Khadri SFR, Pande C (2016) Ground water flow modeling for calibrating steady state using MODFLOW software: a case study of Mahesh River basin. India Model Earth Syst Environ 2:39

Lin YC, Medina MA (2003) Incorporating transient storage in conjunctive stream-aquifer modeling. Adv Water Resour 26(9):1001-1019

Longinelli A, Stenni B, Genoni L, Flora O, Defrancesco C, Pellegrini G (2008) A stable isotope study of the Garda lake, northern Italy: its hydrological balance. J Hydrol 360(1-4):103-116

Lutz A, Thomas JM, Pohll G, McKay WA (2007) Groundwater resource sustainability in the Nabogo Basin of Ghana. J Afr Earth Sci 49:61-70

Mayr C, Lücke A, Stichler W, Trimborn P, Ercolano B, Oliva G, Ohlendorf C, Soto J, Fey M, Haberzettl T, Janssen S, Schäbitz F, Schleser GH, Wille M, Zolitschka B (2007) Precipitation origin and evaporation of lakes in semi-arid Patagonia (Argentina) inferred from stable isotopes $\left(\delta^{18} \mathrm{O}, \delta^{2} \mathrm{H}\right) \mathrm{J}$ Hydrol 334:53-63

Mohanty S, Jha Madan K, Kumar Ashwani, Panda DK (2013) Comparative evaluation of numerical model and artificial neural network for simulating groundwater flow in Kathajodi-Surua inter-basin of Odisha, India. J Hydrol 495:38-51

Mohapatra PK (2011) Environmental imapact of water and sanitation issues. Orissa Water Supply and Sewerage Board, Puri

Mongelli G, Monni S, Oggiano G, Paternoster M, Sinisi R (2013) Tracing groundwater salinization processes in coastal aquifers: a hydrogeochemical and isotopic approach in the $\mathrm{Na}-\mathrm{Cl}$ brackish waters of northwestern Sardinia, Italy. Hydrol Earth Syst Sci 17:2917-2928

Nachiappan RMP, Kumar Bhishm (2002) Estimation of subsurface components in the water balance of lake Nainital using environmental isotopes. Hydrol Sci J 47:41-54 
Navada SV, Rao SM (1991) Study of Ganga river-groundwater interaction using environmental oxygen-18. Isotopenpraxis 27(8):380-384

Onta PR, Das Gupta A (1995) Regional management modeling of a complex groundwater system for land subsidence control. Water Resour Manag 9(1):1-25

Park C, Lee J, Koo M (2013) Development of a fully distributed daily hydrologic feedback model addressing vegetation, land cover, and soil water dynamics (VELAS). J Hydrol 493:43-56

Rao SM (2006) Practical isotope hydrology. New India Publishing Agency, New Delhi

Reeve AS, Warzocha J, Glaser PH, Siegel DI (2001) Regional groundwater flow modeling of the Glacial Lake Agassiz Peatlands, Minnesota. J Hydrol 243(2):91-100

Reichard EG (1995) Groundwater-surface water management with stochastic water supplies: a simulation-optimization approach. Water Resour Res 31(11):2845-2865

Rodriguez LB, Cello PA, Vionett CA (2006) Modeling streamaquifer interactions in a shallow aquifer Choele Choel Island, Patagonia, Argentina. Hydrogeol J 14:591-602

Sharma B, Tyagi S (2014) Significance of environmental isotopes in ground water studies. In: Naithani S, Joshi G, Mohanty SS (eds) Current trends in environmental resources management. Gaura Books Pvt. Ltd., New Delhi, pp 215-221

Sharma B, Singh R, Singh P, Uniyal DP, Dobhal R (2015) Water resource management through isotope technology in changing climate. Am J Water Resour 3(3):86-91

Shaw GD, White ES, Gammons CH (2013) Characterizing groundwater-lake interactions and its impact on lake water quality. J Hydrol 492:69-78. doi:10.1016/j.jhydrol.2013.04.018

Shivanna K, Tirumalesh K, Noble J, Joseph TB, Singh G, Joshi AP, Khati VS. (2008) Isotope techniques to identify recharge areas of springs for rainwater harvesting in the mountainous region of Gaucher area, Chamoli District, Uttarakhand. Curr Sci 94:1003-1011

Simon RB, Bernard S, Meurville C, Rebour V (2015) Flow-through stream modeling with MODFLOW and MT3D: certainties and limitations. Groundwater 53(6):967-971

Singh SK, Mishra GC, Swamee PK, Ojha CSP (2002) Aquifer diffusivity and stream resistance from varying stream stage. J Irrig Drain Eng 128(1):57-61

Su A, Chen Z, Liu J, Wei W (2014) Sustainability of intensively exploited aquifer systems in the north China Plain: insights from multiple environmental tracers. J Earth Sci 25(3):605-611

Ting CS, Zhou Y, Vriesde JJ, Simmers I (1998) Development of a preliminary groundwater flow model for water resources management in the Pingtung Plain. Taiwan Groundw 35(6):20-35

Turner Kevin W, Wolfe Brent B, Edwards Thomas WD (2010) Characterizing the role of hydrological processes on lake water balances in the Old Crow Flats, Yukon Territory, Canada, using water isotope tracers. J Hydrol 386(1-4):103-117

Tyagi JV, Saheb SM, Thomas T, Rao UVN (1993) Groundwater balance study in Puri district of Orissa part I (processing and analysis of data), Case study (AR-127). National Institute of Hydrology, Roorkee

Tyagi JV, Saheb SM, Thomas T, Rao UVN (1995) Seasonal groundwater balance study in Puri district of Orissa part II, case study (AR-164), National Institute of Hydrology, Roorkee

Vandenschrick G, van Wesemael B, Frot E, Pulido-Bosch A, Molina L, Stievenard M, Souchez R (2002) Using stable isotope analysis $\left(\mathrm{D}-{ }^{18} \mathrm{O}\right.$ ) to characterise the regional hydrology of the Sierra de Gador, S-E Spain. J Hydrol 265:43-55

V́azquez-Sũne E, Carrera J, Tubau I, Śanchez-Vila X, Soler A (2010) An approach to identify urban groundwater recharge. Hydrol Earth Syst Sci 14:2085-2097

Vodila G, Palcsu L, Futó Zs, Szántó I (2011) A 9-year record of stable isotope ratios of precipitation in Eastern Hungary: implications on isotope hydrology and regional palaeoclimatology. J Hydrol 400(1-2):144-153

Ward AD, Trimble SW (2004) Environmental Hydrology. Lewis Publishers, Boca Raton, p 475

Wassenaar LI, Athanasopoulos P, Hendry MJ (2011) Isotope hydrology of precipitation, surface and ground waters in the Okanagan Valley, British Columbia, Canada. J Hydrol 411:37-48

West AG, February EC, Bowen GJ (2014) Spatial analysis of hydrogen and oxygen stable isotopes ("isoscapes") in ground water and tap water across South Africa. J Geochem Explor 145:213-222

Winter TC, Harvey JW, Franke OL, Alley WM (1998) Ground water and surface water: a single resource. US Geological survey Circular, Denver, p 79

Xu X, Huang G, Zhan H, Qu Z, Huang Q (2012) Integration of SWAP and MODFLOW-2000 for modeling groundwater dynamics in shallow water table areas. J Hydrol 412-413:170-181

Rao SM, Kumar US, Shivanna K, Sinha UK, Sharma S (2001) Isotope studies on dynamics and sedimentation in lake Naini, India. Use of isotope techniques in lake dynamics investigations. In: Proceedings of a final research co-ordination meeting Rehovot, Israel, IAEA-TECDOC-1206, p 17

Roy G. K (2004) Hydrogeological framework and groundwater development prospects in Puri district, Central Groundwater Board, South Eastern Region, Government of India, Ministry of Water Resource, Bhubaneswar

Yeh Hsin-Fu, Lee Cheng-Hawe, Hsu Kuo-Chin, Chang Po-Hsun, Wang Chung-Ho (2009) Using stable isotopes for assessing the hydrologic characteristics and sources of groundwater recharge. J Environ Eng Manag 19(4):185-191

Yehdeghoa B, Rozanski K, Zojer H, Stichler W (1997) Interaction of dredging lakes with the adjacent groundwater field: an isotope study. J Hydrol 192(1-4):247-270

Zume J, Tarhule A (2008) Simulating the impacts of groundwater pumping on stream-aquifer dynamics in semi-arid north-western Oklahoma, USA. Hydrogeol J 16:797-810 